\title{
Streptomyces nanshensis sp. nov., isolated from the Nansha Islands in the South China Sea
}

Correspondence
Wen-Jun Li
wjli@ynu.edu.cn
Si Zhang
zhangsi@scsio.ac.cn

\author{
Xin-Peng Tian, ${ }^{1}{ }^{2} \dagger$ Yu-Qin Zhang, ${ }^{2} \dagger$ Qing-Xin Li, ${ }^{1}$ Xiao-Yang Zhi, ${ }^{2}$ \\ Shu-Kun Tang, ${ }^{2}$ Si Zhang ${ }^{1,3}$ and Wen-Jun $\mathrm{Li}^{1,2}$
}

${ }^{1}$ Guangdong Key Laboratory of Marine Materia Medica, South China Sea Institute of Oceanology,
Chinese Academy of Sciences, Guangzhou 510301, PR China

${ }^{2}$ Key Laboratory for Microbial Resources of the Ministry of Education, PR China, and Laboratory for Conservation and Utilization of Bio-resources, Yunnan Institute of Microbiology, Yunnan University, Kunming, Yunnan 650091, PR China

${ }^{3}$ Hainan Key Laboratory of Tropical Marine Biotechnology, South China Sea Institute of Oceanology, Chinese Academy of Sciences, Sanya 572000, PR China
The deep sea, covered by water $>2000 \mathrm{~m}$ deep and comprising $>50 \%$ of the total sea surface, is a unique and extreme environment characterized by high pressure, low temperature, lack of light and little nutrition. In deepsea sediments, marine micro-organisms occupy the main ecological niche, which carries out an important role in the recycling of carbon and nitrogen sources on the sea floor. Marine microbes have been paid more attention in recent years, especially Gram-positive bacteria, which comprise about $13 \%$ of the total bacteria in marine sediment environments (Stevens et al., 2007). Streptomycetes exist not only in all kinds of terrestrial environments, but also ubiquitously in marine environments (Pathom-aree et al., 2006), as one of the main groups of marine actinomycetes (Maldonado et al., 2005). During our study on marine actinomycete resources in deep-sea sediments, strain

†These authors contributed equally to this work.

Abbreviations: PG, phosphatidylglycerol; DPG, diphosphatidylglycerol; $\mathrm{PE}$, phosphatidylethanolamine; PI, phosphatidylinositol; PIM, phosphatidylinositol mannosides.

The GenBank/EMBL/DDBJ accession number for the 16S rRNA gene sequence of strain SCSIO $01066^{\top}$ is EU589334.
SCSIO $01066^{\mathrm{T}}$ was recovered from an abyssal sediment sample. Based on the polyphasic data, this strain should be recognized as a member of a novel species of the genus Streptomyces, for which the name Streptomyces nanshensis sp. nov. is proposed.

Strain SCSIO $01066^{\mathrm{T}}$ was isolated from a deep-sea sediment sample, collected in June 2007 from the sea area of the Nansha Islands in the South China Sea $\left(6^{\circ} 40^{\prime} \mathrm{N}\right.$ $\left.113^{\circ} 33^{\prime} \mathrm{E}\right)$ at a depth of $2015 \mathrm{~m}$. The top $10 \mathrm{~cm}$ of sediment surface was obtained aseptically for sampling and then processed for cultivation experiments by using a standard dilution-plating method on ship within $2 \mathrm{~h}$ of sampling. This organism was isolated on Gauze no. 1 medium, modified with $50 \%$ seawater instead of distilled water, after incubation at $28{ }^{\circ} \mathrm{C}$ for 3 weeks. The purified strain was maintained on ISP medium 2 and as $20 \%(\mathrm{w} / \mathrm{v})$ glycerol suspensions at $-20{ }^{\circ} \mathrm{C}$. Biomass for chemotaxonomic and molecular systematic studies was obtained by cultivation using ISP 2 broth medium $\left(28{ }^{\circ} \mathrm{C}\right.$, 1 week, 150 r.p.m.).

Strain SCSIO $01066^{\mathrm{T}}$ grew well on ISP media 2, 3, 4 and 5 (Shirling \& Gottlieb, 1966), Czapek's solution agar 
(Waksman, 1961), nutrient agar (Difco) and potato agar (Waksman, 1961) at $28{ }^{\circ} \mathrm{C}$ after 7, 14, 21 and 28 days, but white aerial mycelia were observed more easily on ISP media 2, 4 and 5 and Czapek's solution agar. The micromorphology was examined by light microscopy (model BH2; Olympus) and scanning electron microscopy [model JEM1010 (Fig. 1a); model JSM5600LV (Fig. 1b) (both from JEOL)], using cells incubated for 14 and 28 days on ISP 2 medium modified with $50 \%$ seawater instead of distilled water. The organism forms an extensively branched substrate mycelium and aerial hyphae that differentiate into long, spiral spore chains; the spore surface is smooth (Fig. 1a, b). No diffusible pigments were observed by comparing the cultures with the most suitable colour chips from the ISCC-NBS colour charts (Kelly, 1964).

Media and procedures used for determination of physiological features and carbon-source utilization were those described by Smibert \& Krieg (1981) and Williams et al. (1989). The temperature, $\mathrm{pH}$ range and tolerance to $\mathrm{NaCl}$ for growth were determined as described by $\mathrm{Xu}$ et al. (2005), using ISP 2 as the basal medium. Antibiotic susceptibility was examined as described by Groth et al. (2004) using antibiotic discs on ISP 2 medium.

Cells of strain SCSIO $01066^{\mathrm{T}}$ were aerobic and Grampositive. Good growth occurred at $\mathrm{pH} 7.0$ and $28{ }^{\circ} \mathrm{C}$ with $0-3 \%(\mathrm{w} / \mathrm{v}) \mathrm{NaCl}$. This organism was susceptible to
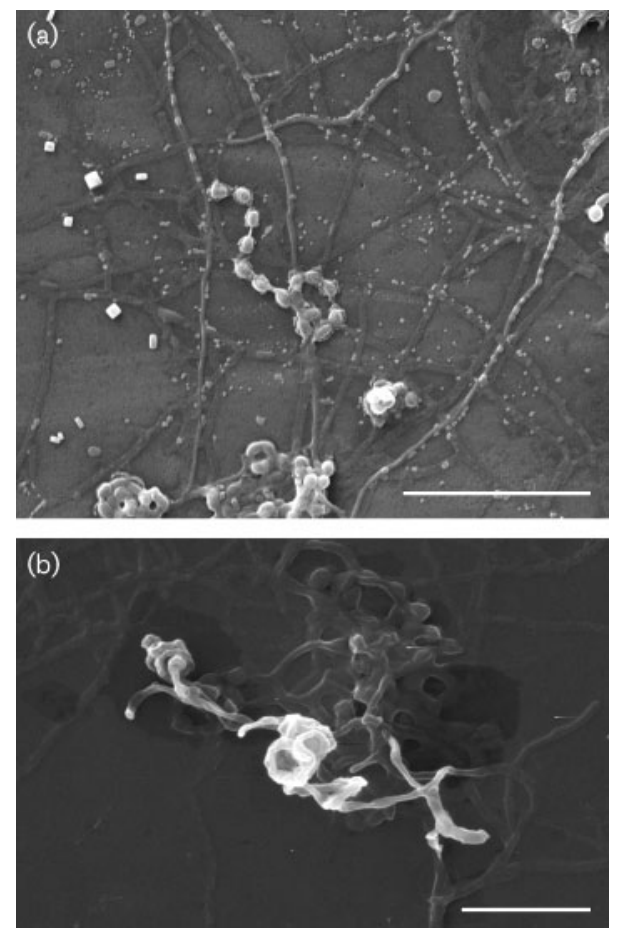

Fig. 1. Scanning electron micrographs of (a) substrate mycelia and (b) spore chains of S. nanshensis SCSIO $01066^{\top}$ after incubation on ISP medium 2 for 4 weeks at $28^{\circ} \mathrm{C}$. Bars, $10 \mu \mathrm{m}(\mathrm{a})$; $5 \mu \mathrm{m}$ (b). amikacin $(30 \mu \mathrm{g}$ per disc), amoxicillin $(10 \mu \mathrm{g}$ per disc $)$, gentamicin $(10 \mu \mathrm{g}$ per disc), lincomycin $(2 \mu \mathrm{g}$ per disc), neomycin $(10 \mu \mathrm{g}$ per disc), netilmicin $(30 \mu \mathrm{g}$ per disc), norfloxacin $(10 \mu \mathrm{g}$ per disc), novobiocin $(30 \mu \mathrm{g}$ per disc), penicillin $\mathrm{G}(10 \mu \mathrm{g}$ per disc), rifampicin $(5 \mu \mathrm{g}$ per disc), streptomycin (10 $\mu \mathrm{g}$ per disc), tetracycline (30 $\mu \mathrm{g}$ per disc), tobramycin $(10 \mu \mathrm{g}$ per disc) and vancomycin $(30 \mu \mathrm{g}$ per disc). It was resistant to ampicillin $(10 \mu \mathrm{g}$ per disc), ciprofloxacin $(5 \mu \mathrm{g}$ per disc), erythromycin $(15 \mu \mathrm{g}$ per disc) and sulfamethoxazole $(23.75 \mu \mathrm{g}$ per disc). Detailed physiological characteristics of this strain are given in the species description.

The isomers of diaminopimelic acid and whole-cell sugars were analysed according to the procedures developed by Hasegawa et al. (1983). Menaquinones were isolated by using the methods of Minnikin et al. (1984) and separated by HPLC (Kroppenstedt, 1982). Phospholipids were extracted and examined by using published procedures (Minnikin et al., 1979; Collins \& Jones, 1980). Fatty acid analysis was performed by using standard methods (Sasser, 1990) and the results were compared with the database of fatty acids in the Microbial Identification System (MIDI, Inc.).

The cell wall of strain SCSIO $01066^{\mathrm{T}}$ contained Ldiaminopimelic acid with whole-cell sugars of galactose and glucose. Phospholipids comprised phosphatidylglycerol (PG), diphosphatidylglycerol (DPG), phosphatidylethanolamine (PE), phosphatidylinositol (PI), phosphatidylinositol mannosides (PIM) and an unknown phospholipid. The menaquinones were MK-9 $\left(\mathrm{H}_{8}\right)(77 \%)$, MK9( $\left.\mathrm{H}_{6}\right)(13.9 \%)$, MK-10 $\left(\mathrm{H}_{8}\right)(3.9 \%)$, MK- $8\left(\mathrm{H}_{8}\right)(2.1 \%)$, MK-9 $\left(\mathrm{H}_{10}\right)(1.9 \%)$ and MK-10(H $\left.\mathrm{H}_{6}\right)(0.7 \%)$. The fatty acids were ai- $\mathrm{C}_{15: 0}(32.42 \%), \mathrm{i}-\mathrm{C}_{16: 0}(25.66 \%), \mathrm{i}-\mathrm{C}_{15: 0}$ $(12.35 \%)$, ai-C $\mathrm{C}_{17: 0}(10.72 \%), \mathrm{i}-\mathrm{C}_{14: 0}(8.75 \%), \mathrm{i}-\mathrm{C}_{17: 0}$ $(2.47 \%), \quad \mathrm{i}-\mathrm{H}-\mathrm{C}_{16: 1} \quad(2.23 \%), \mathrm{C}_{16: 0} \quad(1.89 \%), \quad \mathrm{C}_{15: 0}$ $(0.79 \%)$, ai-C $\mathrm{C}_{13: 0}(0.57 \%)$, i- $\mathrm{C}_{13: 0}(0.48 \%), \mathrm{C}_{16: 1}$ cis 9 $(0.53 \%)$, ai- $\mathrm{C}_{17: 1} \mathrm{C}(0.44 \%)$, ai- $\mathrm{C}_{14: 0}(0.35 \%)$ and $\mathrm{C}_{14: 0}$ $(0.35 \%)$.

Extraction of genomic DNA and PCR amplification of the 16S rRNA gene were done as described previously (Li et al., 2007). Multiple alignments with sequences of the most closely related taxa and calculations of levels of sequence similarity were carried out by using CLUSTAL_X (Thompson et al., 1997). Phylogenetic analyses were performed by using three tree-making algorithms: the neighbour-joining (Saitou \& Nei, 1987), maximum-likelihood (Felsenstein, 1981) and maximum-parsimony (Fitch, 1971) methods. A phylogenetic tree and distance matrix were reconstructed by using the neighbour-joining method of Saitou \& Nei (1987) from $K_{\text {nuc }}$ values (Kimura, 1980, 1983) using MEGA version 4.0 (Tamura et al., 2007). The topology of the phylogenetic tree was evaluated by the bootstrap resampling method of Felsenstein (1985) with 1000 replicates. The $\mathrm{G}+\mathrm{C}$ content of genomic DNA was determined by using the HPLC method (Mesbah et al., 1989).

Based on the almost-complete 16S rRNA gene sequence (1405 bp) of strain SCSIO $01066^{\mathrm{T}}$, BLAST search results 
showed that this new isolate had the highest similarity $(96.5 \%)$ to members of the genus Streptomyces. Preliminary phylogenetic analysis, which included available, almost full-length sequences of type strains of species in the genus Streptomyces, showed that strain SCSIO $01066^{\mathrm{T}}$ was associated with these members of the genus Streptomyces. Morphological and chemotaxonomic characteristics, including cell-wall type, predominant menaqui- nones and major fatty acids, were also consistent with those of members of the genus Streptomyces. All of the above data confirmed that the new isolate should be assigned to the genus Streptomyces.

However, a phylogenetic tree (Fig. 2) based on the closest neighbours of strain SCSIO $01066^{\mathrm{T}}$ showed that the new isolate was associated most closely with Streptomyces

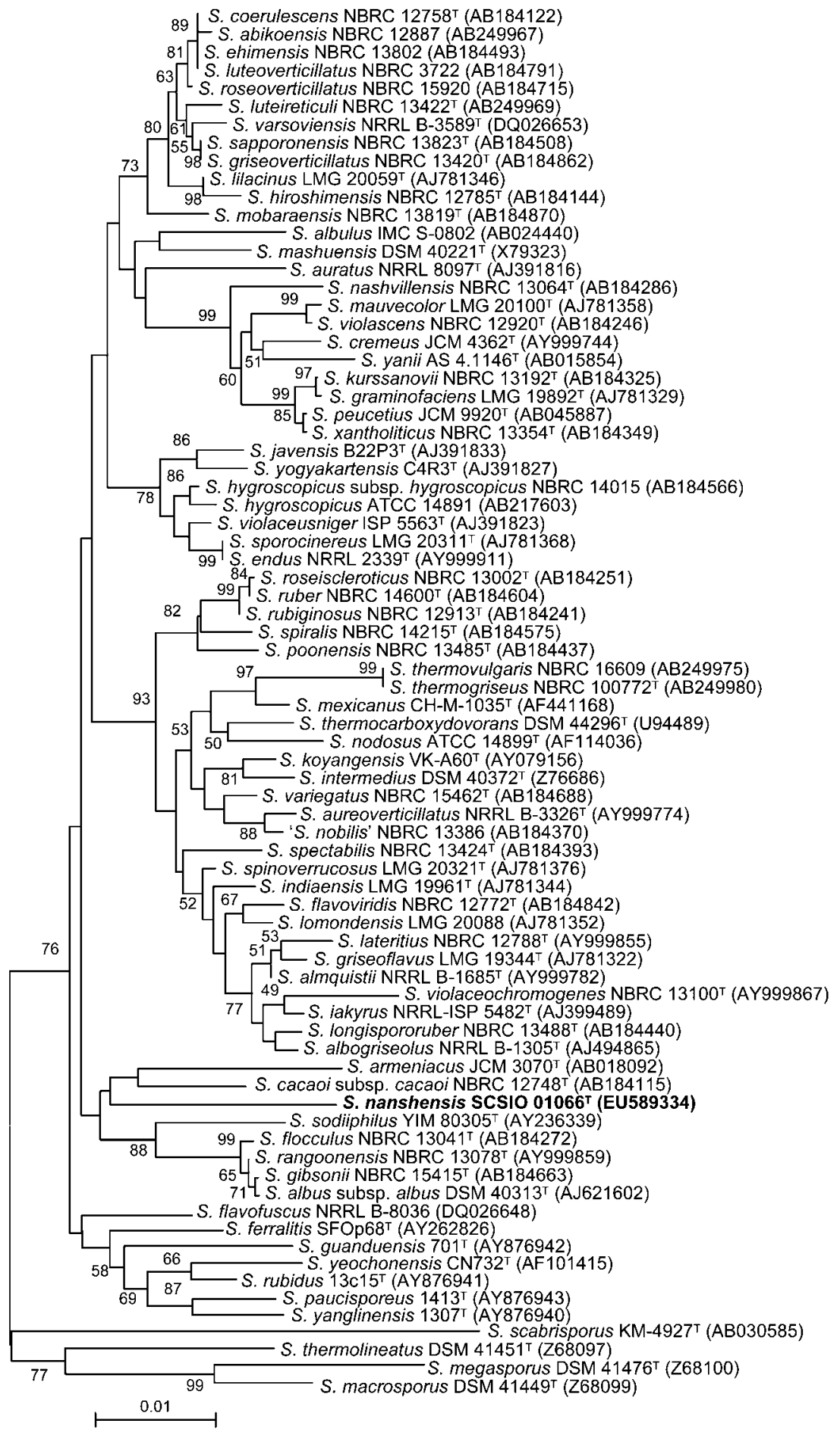

Fig. 2. Phylogenetic tree of strain SCSIO $01066^{\top}$ and its closest relative neighbours within the genus Streptomyces, reconstructed by using the neighbour-joining method. Numbers at nodes are bootstrap values based on 1000 resamplings (only values $>50 \%$ are indicated). Bar, $1 \%$ sequence divergence. 
armeniacus JCM $3070^{\mathrm{T}}$, Streptomyces cacaoi subsp. cacaoi DSM $40057^{\mathrm{T}}$ and Streptomyces sodiiphilus YIM $80305^{\mathrm{T}}$, and these relationships were supported by all tree-making methods used in this study (data not shown). However, the presence of PG in the phospholipid pattern for the new isolate differs greatly from that of other members of the genus Streptomyces. Additionally, strain SCSIO $01066^{\mathrm{T}}$ can be readily distinguished from its most closely related neighbours by the phenotypic characteristics shown in Table 1. Thus, based on the phylogenetic position and phenotypic data, a novel species is proposed for strain SCSIO $01066^{\mathrm{T}}$, to be named Streptomyces nanshensis sp. nov.

\section{Description of Streptomyces nanshensis sp. nov.}

Streptomyces nanshensis (nan.shen'sis. N.L. adj. nanshensis pertaining to the sea area of the Nansha Islands in the southern part of the South China Sea, from where the type strain was isolated).

Aerobic, Gram-positive actinomycete that forms extensively branched substrate mycelia and aerial hyphae that differentiate into long, spiral spore chains. Spore surface is

Table 1. Comparison of characteristics of strain SCSIO $01066^{\top}$ and its most closely related neighbours in the genus Streptomyces

Strains: 1 , SCSIO $01066^{\mathrm{T}}$; 2, S. armeniacus JCM $3070^{\mathrm{T}}$; 3, S. cacaoi subsp. cacaoi NBRC $12748^{\mathrm{T}}$; 4, S. sodiiphilus YIM $80305^{\mathrm{T}}$. Abbreviations: W, white; GW, grey-white; RA, Retinaculiaperti; S, smooth; SP, Spirales; ST, straight; WS, wrinkled surface; +, utilized or reaction positive; -, not utilized or reaction negative; ND, no data available. Data are from this study and Waksman (1961), Wellington \& Williams (1981), Lanoot et al. (2002) and Li et al. (2005).

\begin{tabular}{|c|c|c|c|c|}
\hline Characteristic & 1 & 2 & 3 & 4 \\
\hline Colony colour on ISP 2 & W & W & W & GW \\
\hline Spore surface & S & S & $\mathrm{S}$ & WS \\
\hline Spore-chain morphology & SP & SP & SP & ST to RA \\
\hline $\begin{array}{l}\text { Production of diffusible } \\
\text { pigment }\end{array}$ & - & ND & - & + \\
\hline \multicolumn{5}{|l|}{ Hydrolysis of: } \\
\hline Gelatin & - & + & + & + \\
\hline Starch & - & + & + & - \\
\hline Melanoid pigment & + & - & - & + \\
\hline $\mathrm{H}_{2} \mathrm{~S}$ production & - & ND & - & - \\
\hline \multicolumn{5}{|l|}{ Utilization of: } \\
\hline Glucose & + & + & + & - \\
\hline Arabinose & + & + & + & - \\
\hline Mannitol & + & - & + & - \\
\hline Fructose & + & + & + & - \\
\hline Rhamnose & + & + & - & + \\
\hline Sucrose & + & + & + & - \\
\hline Raffinose & + & + & + & - \\
\hline Inositol & + & ND & - & - \\
\hline Xylose & + & + & + & - \\
\hline
\end{tabular}

smooth. Soluble pigments are not produced. Negative for hydrolysis of Tweens 40 and 80, gelatin, starch, cellulose, milk coagulation and peptonization, $\mathrm{H}_{2} \mathrm{~S}$ production, oxidase and nitrate reduction, but positive for catalase, hydrolysis of Tweens 20 and 60, melanin production and utilization of urea. D-Arabinose, cellobiose, citrate, fructose, D-galactose, D-glucose, inositol, maltose, D-mannitol, D-mannose, raffinose, L-rhamnose, D-ribose, sucrose, trehalose and D-xylose are used as sole carbon sources for growth, but not acetate, dulcitol, D-lactose, D-sorbitol or xylitol. The $\mathrm{pH}, \mathrm{NaCl}$ concentration and temperature ranges for growth are $\mathrm{pH} 6.0-8.0,0-7 \%$ and $10-37{ }^{\circ} \mathrm{C}$, respectively. The cell wall contains L-diaminopimelic acid with whole-cell sugars of galactose and glucose. Phospholipids comprise PG, DPG, PE, PI, PIM and an unknown phospholipid. The predominant menaquinones are MK- $9\left(\mathrm{H}_{8}\right)$ and MK- $9\left(\mathrm{H}_{6}\right)$. The major fatty acids are ai$\mathrm{C}_{15: 0}$, i- $\mathrm{C}_{16: 0}, \mathrm{i}-\mathrm{C}_{15: 0}$, ai- $\mathrm{C}_{17: 0}$ and $\mathrm{i}-\mathrm{C}_{14: 0}$. The $\mathrm{G}+\mathrm{C}$ content of genomic DNA is $72.6 \mathrm{~mol} \%$.

The type strain, SCSIO $01066^{\mathrm{T}}\left(=\right.$ KCTC $19400^{\mathrm{T}}=$ CCTCC AA $208005^{\mathrm{T}}$ ), was isolated from a sediment sample taken at a depth of $2015 \mathrm{~m}$, collected from the Nansha Islands in the South China Sea.

\section{Acknowledgements}

The authors are grateful to Dr Jean Euzéby for support with nomenclature. This research was supported by the Knowledge Innovation Program of the Chinese Academy of Sciences (KZCX2YW-216), the China National Key Program for Base Research (2005CCA04800), the National Basic Research Program of China (no. 2004CB719601), the National Natural Science Foundation of China (no. 30600001) and the Key Project of Chinese Ministry of Education (no. 206139). W.-J. L. was supported by the Program for New Century Excellent Talents in University.

\section{References}

Collins, M. D. \& Jones, D. (1980). Lipids in the classification and identification of coryneform bacteria containing peptidoglycans based on 2,4-diaminobutyric acid. J Appl Bacteriol 48, 459-470.

Felsenstein, J. (1981). Evolutionary trees from DNA sequences: a maximum likelihood approach. J Mol Evol 17, 368-376.

Felsenstein, J. (1985). Confidence limits on phylogenies: an approach using the bootstrap. Evolution 39, 783-791.

Fitch, W. M. (1971). Toward defining the course of evolution: minimum change for a specific tree topology. Syst Zool 20, 406-416.

Groth, I., Rodríguez, C., Schütze, B., Schmitz, P., Leistner, E. \& Goodfellow, M. (2004). Five novel Kitasatospora species from soil: Kitasatospora arboriphila sp. nov., $K$. gansuensis sp. nov., $K$. nipponensis sp. nov., $K$. paranensis sp. nov. and $K$. terrestris sp. nov. Int J Syst Evol Microbiol 54, 2121-2129.

Hasegawa, T., Takizaea, M. \& Tanida, S. (1983). A rapid analysis for chemical grouping aerobic actinomycetes. J Gen Appl Microbiol 29, 319-322.

Kelly, K. L. (1964). Inter-Society Color Council - National Bureau of Standards Color Name Charts Illustrated with Centroid Colors. Washington, DC: US Government Printing Office. 
Kimura, M. (1980). A simple method for estimating evolutionary rates of base substitutions through comparative studies of nucleotide sequence. J Mol Evol 16, 111-120.

Kimura, M. (1983). The Neutral Theory of Molecular Evolution. Cambridge: Cambridge University Press.

Kroppenstedt, R. M. (1982). Separation of bacterial menaquinones by HPLC using reverse phase (RP18) and a silver loaded ion exchanger as stationary phases. J Liq Chromatogr 5, 2359-2387.

Lanoot, B., Vancanneyt, M., Cleenwerck, I., Wang, L., Li, W., Liu, Z. \& Swings, J. (2002). The search for synonyms among streptomycetes by using SDS-PAGE of whole-cell proteins. Emendation of the species Streptomyces aurantiacus, Streptomyces cacaoi subsp. cacaoi, Streptomyces caeruleus and Streptomyces violaceus. Int J Syst Evol Microbiol 52, 823-829.

Li, W.-J., Zhang, Y.-G., Zhang, Y.-O., Tang, S.-K., Xu, P., Xu, L.-H. \& Jiang, C.-L. (2005). Streptomyces sodiiphilus sp. nov., a novel alkaliphilic actinomycete. Int J Syst Evol Microbiol 55, 1329-1333.

Li, W. J., Xu, P., Schumann, P., Zhang, Y. Q., Pukall, R., Xu, L. H., Stackebrandt, E. \& Jiang, C. L. (2007). Georgenia ruanii sp. nov., a novel actinobacterium isolated from forest soil in Yunnan (China) and emended description of the genus Georgenia. Int J Syst Evol Microbiol 57, 1424-1428.

Maldonado, L. A., Stach, J. E. M., Pathom-aree, W., Ward, A. C., Bull, A. T. \& Goodfellow, M. (2005). Diversity of cultivable actinobacteria in geographically widespread marine sediments. Antonie van Leeuwenhoek 87, 11-18.

Mesbah, M., Premachandran, U. \& Whitman, W. B. (1989). Precise measurement of the $\mathrm{G}+\mathrm{C}$ content of deoxyribonucleic acid by highperformance liquid chromatography. Int J Syst Bacteriol 39, 159-167.

Minnikin, D. E., Collins, M. D. \& Goodfellow, M. (1979). Fatty acid and polar lipid composition in the classification of Cellulomonas, Oerskovia and related taxa. J Appl Bacteriol 47, 87-95.

Minnikin, D. E., O'Donnell, A. G., Goodfellow, M., Alderson, G., Athalye, M., Schaal, A. \& Parlett, J. H. (1984). An integrated procedure for the extraction of isoprenoid quinines and polar lipids. J Microbiol Methods 2, 233-241.

Pathom-aree, W., Stach, J. E. M., Ward, A. C., Horikoshi, K., Bull, A. T. \& Goodfellow, M. (2006). Diversity of actinomycetes isolated from Challenger Deep sediment $(10,898 \mathrm{~m})$ from the Mariana Trench. Extremophiles 10, 181-189.
Saitou, N. \& Nei, M. (1987). The neighbor-joining method: a new method for reconstructing phylogenetic trees. Mol Biol Evol 4, 406425.

Sasser, M. (1990). Identification of bacteria by gas chromatography of cellular fatty acids. USFCC Newsl 20, 16.

Shirling, E. B. \& Gottlieb, D. (1966). Methods for characterization of Streptomyces species. Int J Syst Bacteriol 16, 313-340.

Smibert, R. M. \& Krieg, N. R. (1981). General characterization. In Manual of Methods for General Bacteriology, pp. 409-443. Edited by P. Gerhardt, R. G. E. Murray, R. N. Costilow, E. W. Nester, W. A. Wood, N. R. Krieg \& G. B. Phillips. Washington, DC: American Society for Microbiology.

Stevens, H., Brinkhoff, T., Rink, B., Vollmers, J. \& Simon, M. (2007). Diversity and abundance of Gram positive bacteria in a tidal flat ecosystem. Environ Microbiol 9, 1810-1822.

Tamura, K., Dudley, J., Nei, M. \& Kumar, S. (2007). MEGA4: molecular evolutionary genetics analysis (MEGA) software version 4.0. Mol Biol Evol 24, 1596-1599.

Thompson, J. D., Gibson, T. J., Plewniak, F., Jeanmougin, F. \& Higgins, D. G. (1997). The CLUSTAL_X windows interface: flexible strategies for multiple sequence alignment aided by quality analysis tools. Nucleic Acids Res 25, 4876-4882.

Waksman, S. A. (1961). The actinomycetes. In Classification, Identification and Descriptions of Genera and Species, vol. 2, pp. 1363. Baltimore, MD: Williams \& Wilkins.

Wellington, E. M. H. \& Williams, S. T. (1981). Transfer of Actinoplanes armenicacus Kalakoutskii and Kusnetsov to Streptomyces: Streptomyces armeniacus (Kalakoutskii and Kusnetsov) comb. nov. Int J Syst Bacteriol 31, 77-81.

Williams, S. T., Goodfellow, M. \& Alderson, G. (1989). Genus Streptomyces Waksman and Henrici 1943, 339 ${ }^{\mathrm{AL}}$. In Bergey's Manual of Systematic Bacteriology, vol. 4, pp. 2452-2492. Edited by S. T. Williams, M. E. Sharpe \& J. G. Holt. Baltimore, MD: Williams \& Wilkins.

Xu, P., Li, W. J., Tang, S. K., Zhang, Y. Q., Chen, G. Z., Chen, H. H., Xu, L. H. \& Jiang, C. L. (2005). Naxibacter alkalitolerans gen. nov., sp. nov., a novel member of the family Oxalobacteraceae isolated from China. Int J Syst Evol Microbiol 55, 1149-1153. 